\title{
Biomass Burning in South America: Transport Patterns and Impacts
}

\author{
Ana Graciela Ulke ${ }^{1}$, Karla María Longo ${ }^{2}$ and Saulo Ribeiro de Freitas ${ }^{3}$ \\ ${ }^{1}$ Departamento de Ciencias de la Atmósfera y los Océanos, Facultad de \\ Ciencias Exactas y Naturales, Universidad de Buenos Aires, Buenos Aires \\ ${ }^{2}$ Divisão de Geofisica Espacial, Instituto Nacional de Pesquisas Espaciais, \\ São cbsé dos Campos, São Paulo \\ ${ }^{3}$ Centro de Previsão de Tempo e Estudos Climáticos, Instituto Nacional de Pesquisas \\ Espaciais, Cachoeira Paulista, São Paulo \\ ${ }^{1}$ Argentina \\ ${ }_{2,3}^{3}$ Brazil
}

\section{Introduction}

The Andes Mountains barrier and the interaction with the easterly trade winds, and the flow associated to the South Atlantic Subtropical High (SASH) are responsible of a key feature of the low-level atmospheric circulation and climate: the so called South American Low Level Jet (SALLJ). The SALLJ is a wind maximum immersed in a pole-ward and moist current with a cross stream mean dimension in the mesoscale, which has been identified as an efficient dynamical mechanism to transport heat and humidity from tropical to subtropical latitudes. The SALLJEX (South American Low Level Jet Experiment) field campaign provided a unique data set for the study and better understanding of the SALLJ (Vera et al., 2006). The SALLJ feeds and controls the life cycle of the mesoscale convective systems over an area that includes the Del Plata basin, and accounts for an important fraction of the precipitation in southern South America, thus influencing the water balance in the region (Nicolini et al., 2002; Saulo et al., 2000). The SALLJ has also being pointed as an important agent to transport and mix other biogeochemical components (Paegle, 1998).

The orographic control of the Andes favouring the poleward flow causes the persistency of the SALLJ all year round, being only episodically interrupted by mid-latitude transient systems arriving in the subtropical South America (SA) (James \& Anderson, 1984; NoguesPaegle et al., 1998). While during the summer this flow has a net poleward component, in the winter it has an eastward tendency up in the mid-latitudes, with an outflow toward the South Atlantic Ocean broadly ranging from $20^{\circ} \mathrm{S}$ to $40^{\circ} \mathrm{S}$, strongly depending on the position of the SASH. Nogues-Paegle \& Mo (1997) found an intraseasonal meridional seesaw of dry and wet conditions over tropical and subtropical South America during austral summer in which the South Atlantic Convergence Zone (SACZ) and the low-level stream intensify alternatively. Over the central and north bands of SA during the winter, the climate is strongly influenced by the northward motion of the Inter-tropical Convergence Zone (ITCZ) and the westward displacement of SASH, composing a scenario of a low levels high pressure system over the continent, with light winds and most of the convection being shifted to the northern part of the Amazon and very little precipitation. 
This is the climatological scenario of the SA dry season that eases the Tropical Forest and Cerrado biomes anthropogenic crackdown, followed by the biomass burning. In fact, the vegetation fire activity had been since remote times incorporated, as a supposedly acceptable practice, by the local culture to expand pasture and crop lands and even as a regular agricultural harvest tool for some types of produce, such as sugar cane. Every year during the dry season hundreds of thousands of fire spots and the produced thick regional smoke plume, which covers an area of about 4-5 millions of square kilometres, have been detected by satellite observation over SA.

As the SALLJ drives an important mass exchange from the tropical Amazon to the sub-tropics it is predictable that this low level flow could as well play an important role intercommunicating regional climate changes in the Amazonian basin to the southern South American basins. This paper examines the mass exchange between the Amazon basin and the subtropical SA patronized by the SALLJ during the dry/burning season, when the transport of heat and moist occurs associated with the transport of biomass burning smoke aerosol particles.

\section{Methods}

A diagnose of the occurrence of the SALLJ events for the 2002 was performed based on the modified Bonner's first criterion for the strength and vertical shear of the wind field (Bonner, 1968; Saulo et al., 2000), using the 6-hourly analysis of the Global Data Assimilation System (GDAS) of the National Centers for Environmental Prediction (NCEP). This data set has one-degree horizontal resolution and is available every synoptic time $(0000,0600,1200$ and 1800 UTC), at 26 vertical pressure levels.

The information about fire spots over South America is obtained with remote sensors and after processing, it is freely available at http://www.cptec.inpe.br. The observations of aerosols in Buenos Aires that could give information of the intrusion of the regional smoke plumes consist on columnar aerosol content and derived quantities obtained from measurements at the CEILAP-BA $\left(34.5^{\circ} \mathrm{S}, 58^{\circ} \mathrm{W}\right)$ (Buenos Aires) site of the AErosol RObotic NETwork (AERONET) from National Atmospheric and Science Administration (NASA) (http://aeronet.gfsc.nasa.gov).

The on-line atmospheric transport model CATT-BRAMS (Coupled Aerosol and Tracer Transport model to the Brazilian developments on the Regional Atmospheric Modeling System) was used to simulate the atmospheric transport of biomass burning smoke during the dry season of 2002. A detailed description of the CATT-BRAMS system can be seen at Freitas et al., 2009; Longo et al., 2010). The system considers the emission, transport and transformations of particulate matter (PM2.5) and gases (CO) and it is run operatively at Centro de Previsão de Tempo e Estudos Climáticos (CPTEC) with $40 \mathrm{~km}$ resolution over South America. It provides 72-hour predictions of the above mentioned aerosols and gases as well as the meteorological fields. Two SALLJ events were selected to perform a more in depth analysis of the transport patterns and the aerosol dispersion. The synoptic environment in which they took place was studied and the resulting spatial and temporal distributions of aerosols obtained with the CATT-BRAMS modelling system for each case were analysed.

\section{Results}

\subsection{SALLJ and biomass burning in 2002}

The occurrence of SALLJ in the 2002 was then determined and the pattern found was in agreement with previous studies for other years. Figure 1 shows the percent relative frequencies of SALLJ obtained for each month. 


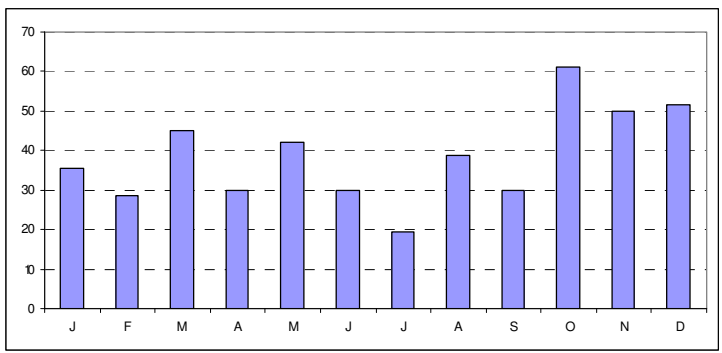

Fig. 1. Monthly relative frequencies of SALLJ (\%) during 2002.

The low level flow was present all through the 2002 year, though presenting variability in its strength, frequency and location mainly related to the different synoptic conditions, and the greater scale climatological scenario. The higher frequencies of occurrence of SALLJ are observed in October and the lower in July. As previously mentioned, the aim of the present study is to relate the low-level jet east of the Andes with the dispersion of biomass burning products in South America. Figure 2 presents the number of fire spots in South America for each month in 2002. The important increase from August to October -namely the biomass burning season- is clearly evident. In consequence, we will restrict the further analysis to the events in those months.

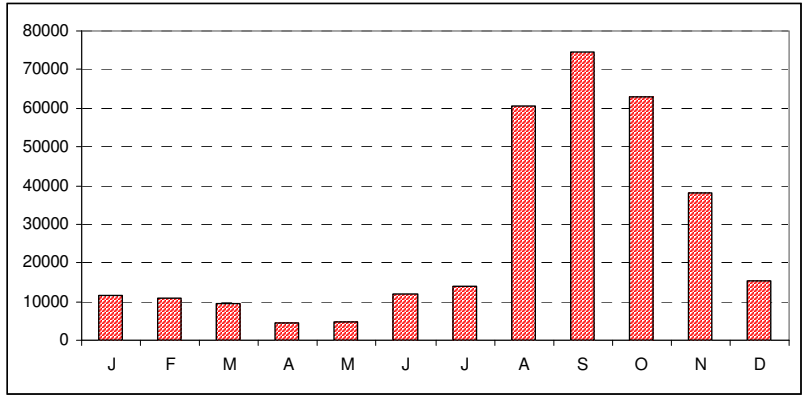

Fig. 2. Number of fires in South America per month during 2002.

The main characteristics of the mean low-level flow are depicted in the composite fields, obtained averaging the days that comprise the SALLJ events for the burning season months (Figure 3). August and October were characterized by a northerly oriented flow, when mainly the northeast of Argentina was under its influence. In September the mean pattern was more north-westerly oriented with an outflow towards the Atlantic Ocean, over passing the southern region of Brazil. August shows the southernmost penetration, greatest horizontal wind speed gradient and vertical wind speed shear. During this month, the events are less frequent but much stronger. In the opposite, in October, there is a higher recurrence of generally weaker events. The mean low level north-westerly flow organizes at about $15^{\circ} \mathrm{S}$ and extends southward reaching $30-35^{\circ} \mathrm{S}$.

The associated circulation patterns in conjunction with the occurrence of biomass burning caused the transport of aerosols and gases towards different regions with diverse impacts. Figure 4 shows the composites of the modelled vertically integrated aerosol optical thickness at $500 \mathrm{~nm}$ (AOT500) and the flow pattern for the SALLJ events. The mean plume 
and flow are very well reproduced and the higher aerosol concentrations are directly related to the greater emissions during September and October.
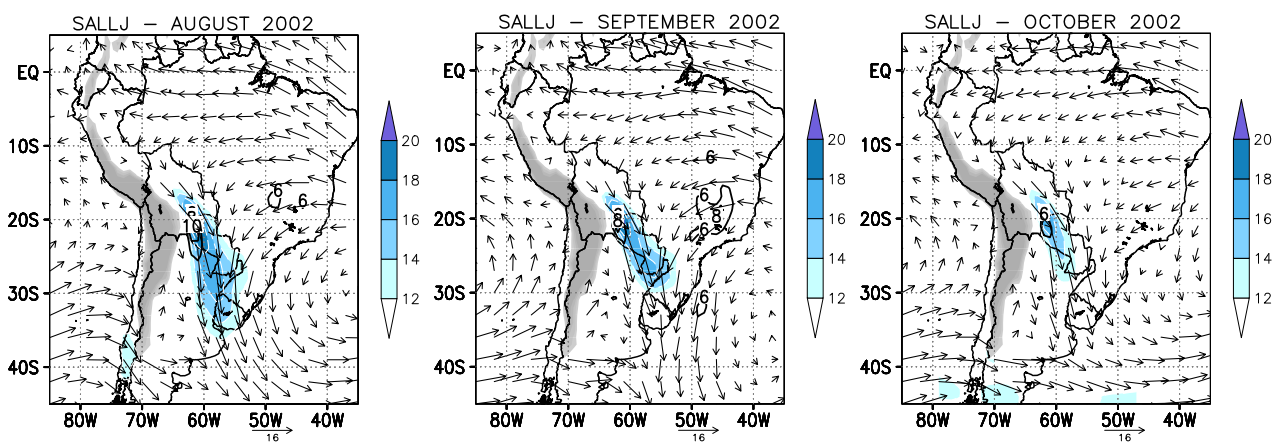

Fig. 3. Monthly composite fields for SALLJ during the biomass burning season: wind (vector); wind speed (shaded) at $850 \mathrm{hPa}$ and wind shear between $850 \mathrm{hPa}$ and $700 \mathrm{hPa}$ (black contours). Shaded: wind intensity stronger than $12 \mathrm{~m} \mathrm{~s}^{-1}$. Black contours: wind shear greater than $6 \mathrm{~m} \mathrm{~s}^{-1}$. Terrain elevations higher than $1500 \mathrm{~m}$ are shown.


Fig. 4. Monthly composite fields for AOT500nm (shaded) and wind at 1400m (streamlines) for the SALLJ events during the biomass burning season. Fields are masked in terrain elevations higher than $1500 \mathrm{~m}$.

The temporal behaviour of the AOT at the AERONET site in Buenos Aires is depicted in Figure 5 for the sub-samples SALLJ and NO-SALLJ along with the comparison with the CATT-BRAMS predicted values. The model is able to capture the evolution of the aerosol concentration. The underestimation of the values is linked to the comparison of point measurements and the model results resolution.

The relationship between the Ångström coefficient and the AOT is frequently used to get more information about the aerosol characteristics. The greater aerosol load observed during the SALLJ events is clearly associated to higher Ångström coefficients in agreement with the literature (Figure 6). 


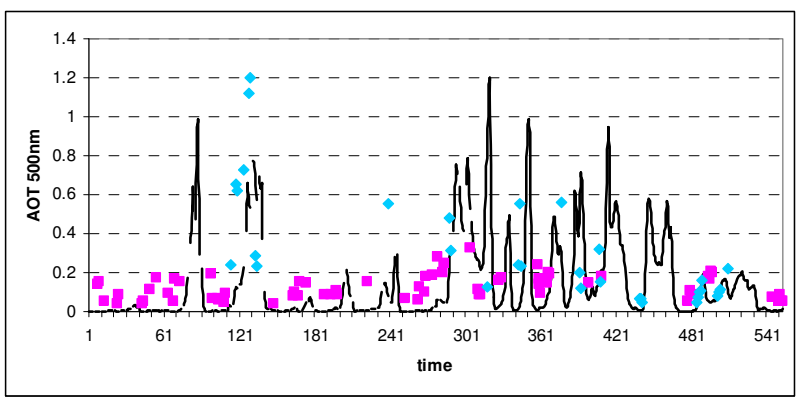

Fig. 5. Comparison of AOT 500nm obtained at the Buenos Aires AERONET site (dots, diamond: SALLE, square: NO-SALLe) and CATT-BRAMS model (line) from August to October 2002.

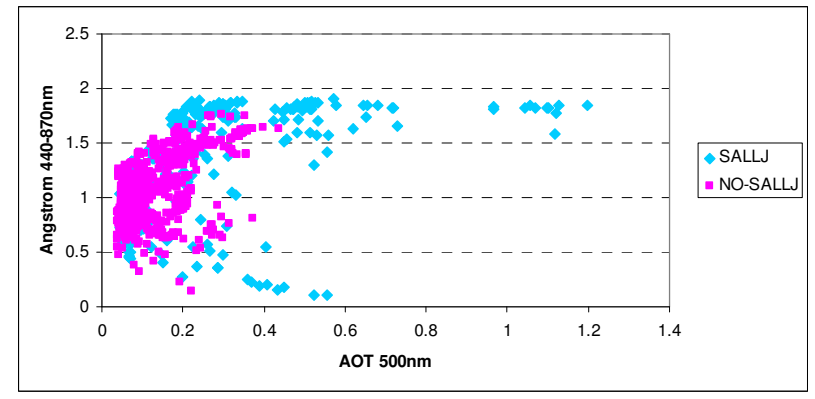

Fig. 6. Variation of the Ångström coefficient (440-870nm) with the AOT 500nm obtained from the measurements at the Buenos Aires AERONET site (dots, diamond: SALLC, square: NO-SALLE) from August to October 2002.

\subsection{Case study: august 2002}

A prolonged SALLJ event that occurred in conjunction with biomass burning took place from 23 to 28 August. The low-level jet had an important latitudinal extent and strength with a pattern that varied according to a baroclinic synoptic environment.

\subsubsection{Meteorological environment and SALLJ features}

Figure 7 depicts the $1000 \mathrm{hPa}$ geopotential height and the 500/1000 hPa thickness fields for selected days during the event. On 23 August, the western branch of the SASH was over an important extension of SA and the low-level flow was from the $\mathrm{N}$ as far as $40^{\circ} \mathrm{S}$. In the southernmost edge of SA, a baroclinic region -oriented NW to SE- was present and deep low-pressure systems were moving south-eastward. During the following day, a geopotential trough developed over central Argentina. The thickness field showed the associated maximum depth. There was a persistent N-NW flow over south-eastern SA. On 25 August, a further deepening of the trough over central Argentina occurred. The baroclinic region related to the cold front was located between $30^{\circ} \mathrm{S}$ and $40^{\circ} \mathrm{S}$ and moved towards the northeast. The low-pressure system behind the cold front weakened. There was a strong channelling of the low-level flow between the trough and the western region of the SASH. Twenty-four hours later, the baroclinic zone approached the southern region of Buenos Aires. A deep thickness trough was present over the eastern Pacific Ocean. Central 
Argentina was still with the minimum geopotential. The flow from the north at low levels persisted. On 27 August, the situation was almost similar, with the new system strengthening and moving eastward and starting to surpass the Andes barrier. The northern low-level flow was still present over south-eastern SA and the low pressure further deepened over central Argentina. On 28 August, the system was able to reach eastern Argentina. The associated cold front presented a nearly north-south orientation and moved eastward towards the Atlantic Ocean. The low-pressure system over Argentina deepened and the low-level north-western flow persisted. During 29 August the cold sector of the front moved past Buenos Aires and Uruguay and the related surface cyclone, centred near $40^{\circ} \mathrm{S}$ and $55^{\circ} \mathrm{W}$, deepened. The near-surface airflow over south-eastern SA was from the N$\mathrm{NE}$ sector and from the $\mathrm{S}$ in Buenos Aires. On 30 August, the baroclinic region in the $500 / 1000 \mathrm{hPa}$ thickness field was located at $30^{\circ} \mathrm{S}$, with zonal orientation. The surface lowpressure system had its maximum depth at 0600 UTC and then started to fill while travelling to the east over the Atlantic Ocean. Central Argentina had relatively higher surface pressure. The near surface flow was from the $S$ over northern Argentina. During the final day of the study period (31 August) the baroclinic region was in southern Brazil, colocated with a surface col region. Argentina had near surface southerly winds. The surface cyclone was in the occlusion stage at 1800 UTC.
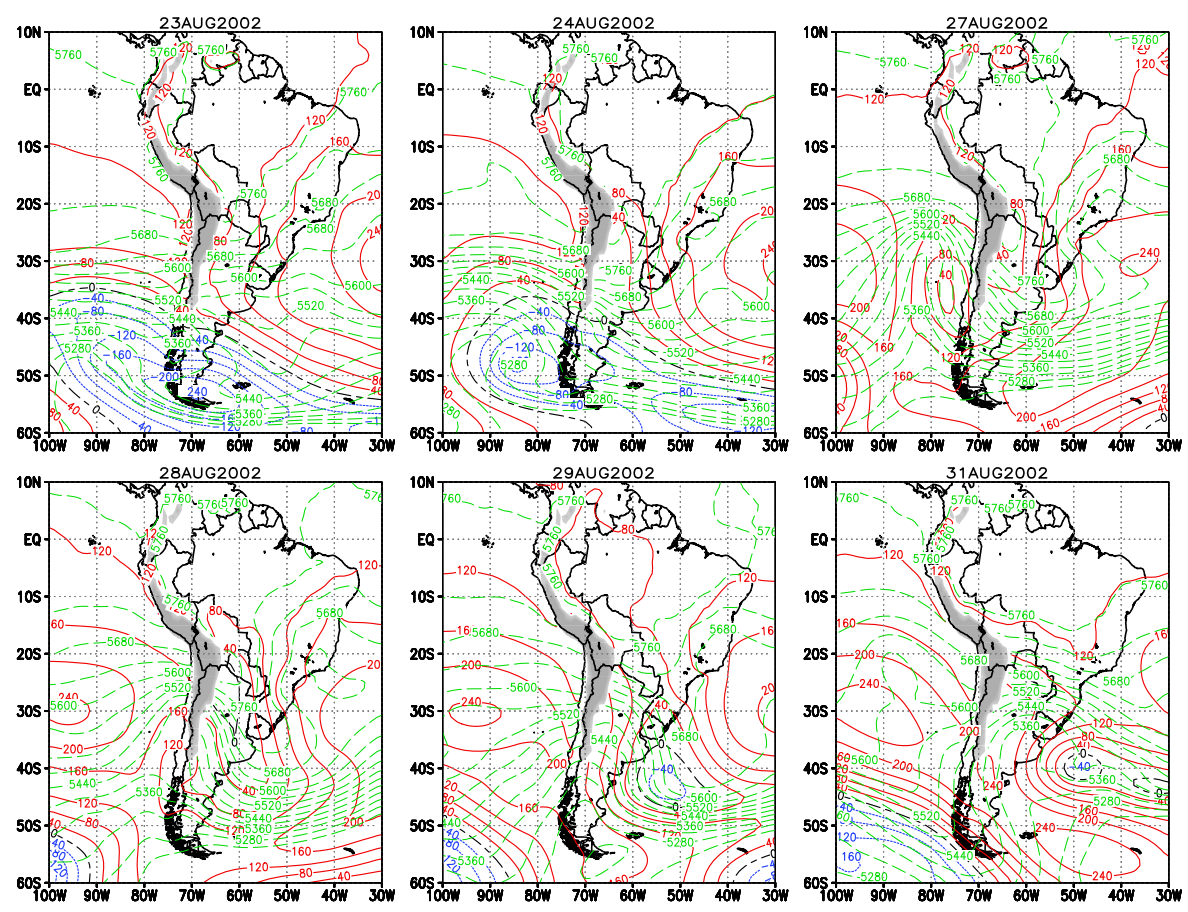

Fig. 7. Daily fields of $1000 \mathrm{hPa}$ geopotential height (red solid (positive), blue dot (negative) contours) and 500/1000 hPa thickness (green long dash contours) (both every $40 \mathrm{mgp}$ ), from 23 to 31 August. Terrain elevations higher than $1500 \mathrm{~m}$ are shaded.

The wind field at $850 \mathrm{hPa}$ and the regions that verified the modified Bonner criteria for some selected days are depicted in Figure 8. On 23 August, the affected region was from central 
Bolivia to north-eastern Argentina, part of Uruguay and southern Brazil. The jet core was located over northern Paraguay. The related flow was from the N-NW sector. During the following day, the SALLJ had increased strength and vertical shear, as well as more spatial extension. The southernmost edge was near $40^{\circ}$ S. On 25 August, the NW-SE region associated with the SALLJ had a greater latitudinal extension and the low-level flow was from the northwest and stronger due to the westward displacement of the Atlantic anticyclone. During the next day, the SALLJ had a smaller southward penetration and reached only $35^{\circ} \mathrm{S}$. This was due to the advance of the cold front that was located past $40^{\circ} \mathrm{S}$ at the $850-\mathrm{hPa}$ level over the ocean. The flow was more northerly oriented. The jet core was over western Paraguay and northern Argentina.
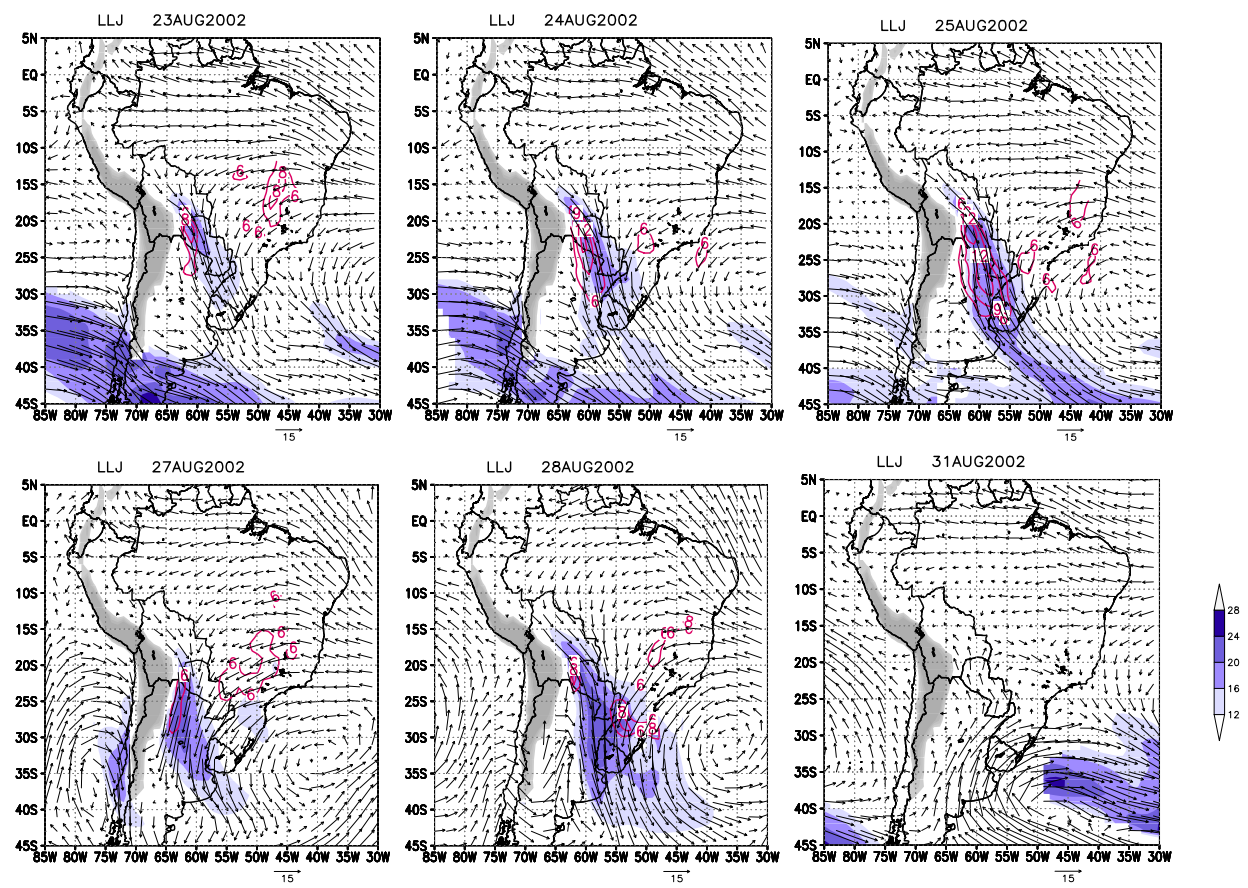

Fig. 8. Daily SALLJ fields from 23 to 31 August. Wind (vector); wind speed (shaded) at 850 $\mathrm{hPa}$ and wind shear between $850 \mathrm{hPa}$ and $700 \mathrm{hPa}$ (contours). Shaded: wind intensity stronger than $12 \mathrm{~m} \mathrm{~s}^{-1}$. Contours: wind shear greater than $6 \mathrm{~m} \mathrm{~s}^{-1}$. Terrain elevations higher than 1500 $\mathrm{m}$ are shown.

On 27 August, the SALLJ was present over northern and central Argentina. The flow was from the N-NE sector mostly governed by the western region of the anticyclone centred near $32.5^{\circ} \mathrm{S}$ and $40^{\circ} \mathrm{W}$ over the Atlantic Ocean. During 28 August, the jet strengthened and spread, reaching the latitudes near $45^{\circ} \mathrm{S}$ and extending from $65^{\circ} \mathrm{W}$ to $40^{\circ} \mathrm{W}$. The SALLJ reinforced due to the new cold front that was located near $60^{\circ} \mathrm{W}$ at 1200 UTC with northsouth orientation. On 29 August, the front reached Paraguay and south-eastern Brazil. The wind field at $850 \mathrm{hPa}$ shows clearly the northwest wind ahead of the front whereas the winds behind were strong, from the southwest. The region spanned by the strongest winds 
has the typical shape of the frontal zone but the wind field did not verify the Bonner's criteria. During 30 August, the north-western edge of the frontal zone was over São Paulo, with the southerly winds blowing clear and dry air over South America up to $15^{\circ} \mathrm{S}$. The convergence in the airflow is related to the surface cold front and the baroclinic region near São Paulo. The situation persisted on 31 August. SALLJ did not occur either. During this particular event, an important southward penetration of the low-level jet occurred and the associated moisture convergence at the exit region of the current favoured the development of convective systems south of $40^{\circ} \mathrm{S}$, which strengthened mostly over the Atlantic Ocean. The interaction with the cold front further contributed to the convection.

\subsubsection{Concentration behaviour}

The evolution and spatial extent of the smoke plume is studied through the behaviour of the AOT500. Figure 9 shows the modelled AOT500 and the horizontal flow at $1400 \mathrm{~m}$ above the surface, at selected days during the analyzed period. On 23 August the smoke plume showed a relative maximum close to the emission sources, centred near $10^{\circ} \mathrm{S}$ and $60^{\circ} \mathrm{W}$, with values higher than 2 . The smoke plume had its greater longitudinal extension between
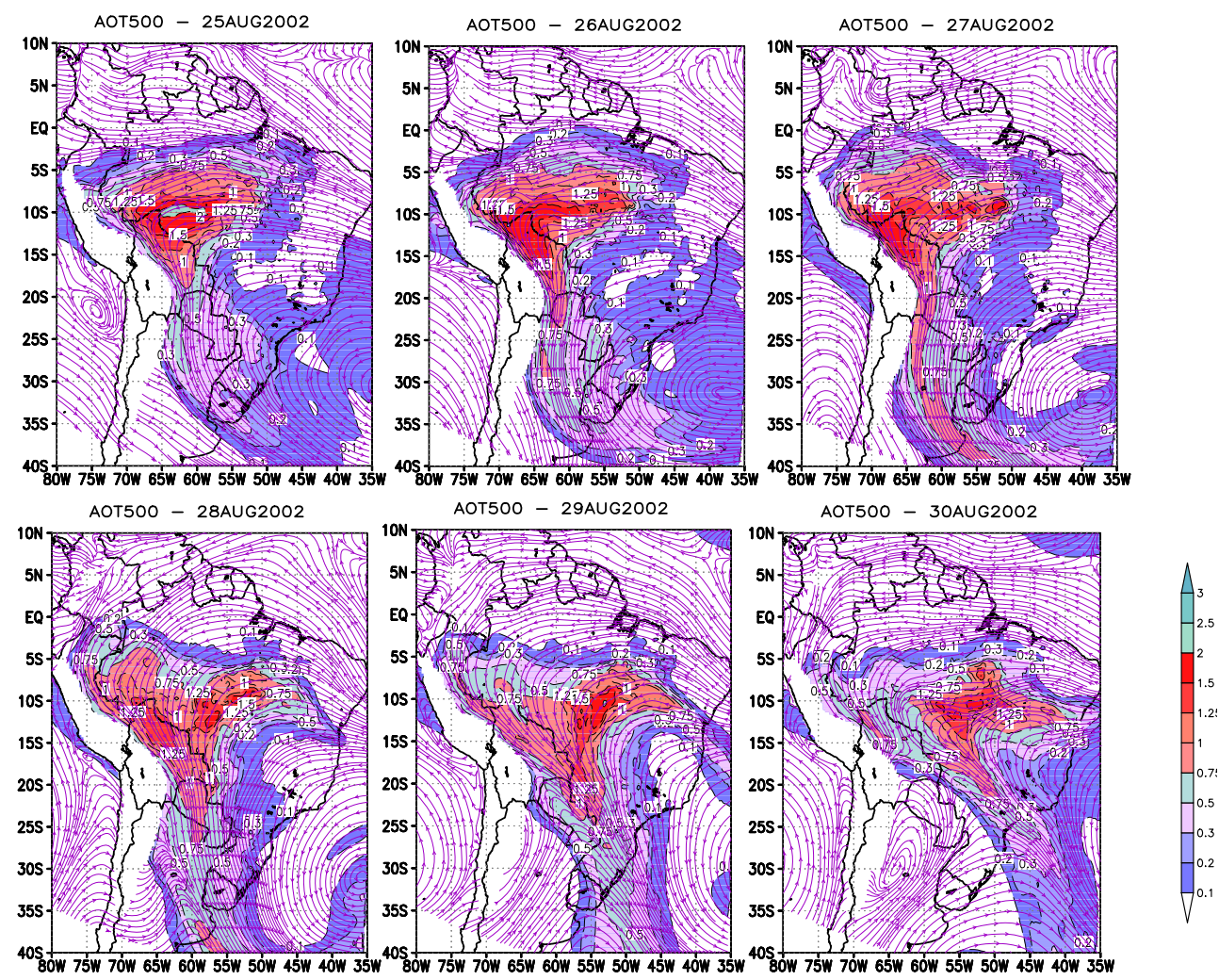

Fig. 9. Daily means of AOT500nm from 23 to 31 August (shaded) and wind field (streamlines) at $1400 \mathrm{~m}$ above the surface. 
the Equator and $10^{\circ} \mathrm{S}$. This feature is related with the dominance of the easterlies in that region. An outflow zone from South America towards the west is observed between $5^{\circ} \mathrm{S}$ and $10^{\circ} \mathrm{S}$. To the south, at higher latitudes, the smoke plume had an important branch oriented from the NW to the SE reaching the latitude $20^{\circ} \mathrm{S}$, with AOT values higher than 0.5 . These features are due to the transport patterns at low and middle atmospheric levels, which were dominated by the flow at the western branch of the high-pressure system and the channelling effect of the Andes barrier.

On 24 August, the region with higher AOT values near the sources increased. The smoke plume had a greater latitudinal extent over Argentina, reaching $35^{\circ} \mathrm{S}$. The core of the lowlevel jet was associated with a relative minimum. Contrarily, a relative maximum over northern Argentina appears west of the jet core. On 25 August the southern edge of the plume continues to travel towards higher latitudes and presents a shape associated with the anticyclonic circulation and the barrier effect of the Andes. Optical depths ranging from 0.3 to 0.5 cover NE of Argentina and Uruguay. An outflow region from South America towards the west is observed between $5^{\circ} \mathrm{S}$ and $15^{\circ} \mathrm{S}$. On 26 August, Buenos Aires had AOT values between 0.5 and 0.75 . The smoke plume has N-S orientation from latitudes near $15^{\circ} \mathrm{S}$ to $30^{\circ}$ S. The greater values are observed near the sources, over central Brazil and Bolivia. On its southernmost extreme the plume shows a curvature associated with the high-pressure system centred over the Atlantic Ocean, near $32^{\circ} \mathrm{S}$ and $35^{\circ} \mathrm{W}$. Córdoba is affected by aerosol optical thicknesses ranging from 0.75 to 1, which are higher than those at Buenos Aires.

On 27 August the smoke plume reached latitudes higher than $40^{\circ} \mathrm{S}$. The AOT over Buenos Aires ranged from 0.75 to 1 . On 28 August, the cold front succeeded in crossing the Andes and reached Argentina and afterwards, the plume started to be displaced towards the east but was still over Buenos Aires due to its pre-frontal location. During the next day, the smoke plume displaced towards the northeast, owing to the fast movement of the cold front, and reached southern Brazil. On 30 August the plume had clearly the shape of the frontal zone and reached São Paulo. During the next day the surface cold front was stationary over São Paulo. There is a region associated to the postfrontal anticyclone with a low-level recirculation of the aerosols towards the west of the plume centre. This occurs at the northwestern edge of the frontal region, where the forced convection is weaker.

\subsubsection{Meridional PM2.5 and water vapour transport}

Vertical cross sections at latitudes $15^{\circ} \mathrm{S}, 25^{\circ} \mathrm{S}$ and $35^{\circ} \mathrm{S}$, across the smoke plume contribute to depict the distribution of the meridional transport of PM2.5 (in $\mu \mathrm{gm}^{-2} \mathrm{~s}^{-1}$ ) (Figure 10) and water vapour mixing ratio (in gmkg-1 $\mathrm{s}^{-1}$ ) (Figure 11). The cross-sections clearly illustrate the role of the SALLJ as a transport mechanism. In general, the meridional transport of PM2.5 is limited to the layer between the surface and $4000 \mathrm{~m}$ and the higher values are near the emission sources. In the case of the water vapour the vertical extent is greater, reaching $8000 \mathrm{~m}$.

At $15^{\circ}$ S (Figure 10a), on 23 August, the meridional flux of PM2.5 was mainly southward and on the layer between 1000 and $4000 \mathrm{~m}$, with the maximum located between 1500 and $2000 \mathrm{~m}$ with values between -60 and $-180 \mu \mathrm{gm}^{-2} \mathrm{~s}^{-1}$. The transport was on a narrow region east of the Andes range, centred at $65^{\circ} \mathrm{W}$. During the following day, the level of maximum meridional transport was closer to the surface and the longitudinal extent increased. The values were similar than those on the previous day. On 25 August, two relative maxima were present, one close to the surface at $65^{\circ} \mathrm{W}$ and the other one between 1500 and $3500 \mathrm{~m}$ above the ground at $62.5^{\circ} \mathrm{W}$, ranging from -60 to $-300 \mu \mathrm{gm}^{-2} \mathrm{~s}^{-1}$. During the following day, 
the conditions were almost similar, but the maximum close to the surface weakened. During 27 August, the southward transport east of the Andes was comparable, ranging from -180 to $-240 \mathrm{\mu gm}^{-2} \mathrm{~s}^{-1}$ and a secondary maximum west of the mountain range near $3000 \mathrm{~m}$ was present. On 28 and 29August, the southward transport was mainly in the layer between the surface and $3000 \mathrm{~m}$, with a longitudinal extent from $72.5^{\circ} \mathrm{W}$ to $55^{\circ} \mathrm{W}$. The maximum values varied from -240 to $-360 \mu \mathrm{gm}^{-2} \mathrm{~s}^{-1}$. A narrow elevated maximum occurred, at upper levels and $40^{\circ} \mathrm{W}$. On 30 August, the southerlies reached this latitude, and a northward transport

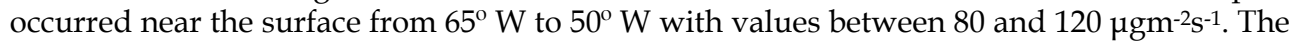
southward transport persisted at upper levels close to the Andes, but gradually vanished according to the cold front movement. During 31 August, the northward flux near the

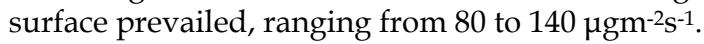

At $25^{\circ} \mathrm{S}$ (Figure 10b), on 23 August, the meridional flux showed a maximum of $-120 \mu \mathrm{gm}^{-2} \mathrm{~s}^{-1}$ centred at $60^{\circ} \mathrm{W}$. The next day the maximum flux occurred westward, at $62.5^{\circ} \mathrm{W}$ and ranged from -120 to $-240 \mu \mathrm{gm}^{-2} \mathrm{~s}^{-1}$. During 25 August, the location was similar and the values increased, varying from -180 to $-360 \mathrm{\mu gm}^{-2} \mathrm{~s}^{-1}$. On the following two days, one region of maximum transport was located close to the Andes from surface up to $3500 \mathrm{~m}$, with values that ranged from -300 to $-660 \mathrm{\mu gm}^{-2} \mathrm{~s}^{-1}$ and the second one, was near the surface centred at $57.5^{\circ} \mathrm{W}$, varied from -60 to $-180 \mu \mathrm{gm}^{-2} \mathrm{~s}^{-1}$ and spanned ten degrees east of $65^{\circ} \mathrm{W}$.
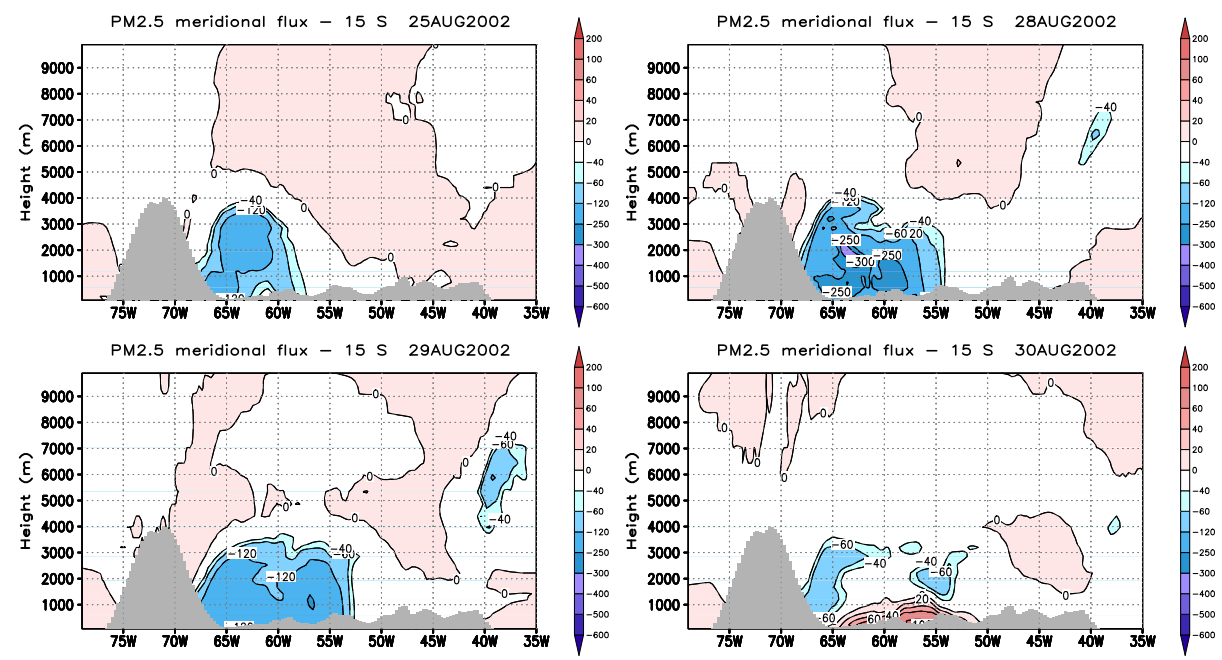

Fig. 10a. Vertical cross-sections at $15^{\circ} \mathrm{S}$ of PM2.5 meridional transport $\left(\mu \mathrm{gm}^{-2} \mathrm{~s}^{-1}\right)$ against the height above the surface. Terrain height profile is included.

During 27 August, there is also a transport towards the south between 3000 and $4000 \mathrm{~m}$ west of the Andes. The next day, the transport had similar longitudinal and vertical span and values from -360 to $-600 \mu \mathrm{gm}^{-2} \mathrm{~s}^{-1}$. By 29 August the southward flux was -180 to $-600 \mu \mathrm{gm}^{-2} \mathrm{~s}^{-1}$ between $62.5^{\circ}$ and $50^{\circ} \mathrm{W}$ and the northward transport was centred at $60^{\circ} \mathrm{W}$, ranging from 60 to $260 \mu \mathrm{gmm}^{-2} \mathrm{~s}^{-1}$. During 30 August the northward flux occurred between $63^{\circ}$ and $50^{\circ} \mathrm{W}$ and values from 20 to $60 \mathrm{\mu gm}^{-2} \mathrm{~s}^{-1}$ and towards the south in upper levels at $47^{\circ} \mathrm{W}$ ranging from -

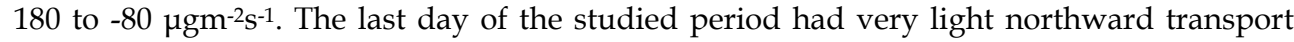
smaller and equal than $20 \mathrm{\mu gm}^{-2} \mathrm{~s}^{-1}$, and southward flux in upper levels from $45^{\circ}$ to $40^{\circ} \mathrm{W}$ with a maximum of $-60 \mu \mathrm{gm}^{-2} \mathrm{~s}^{-1}$. 
Figure 10c illustrates the PM2.5 meridional flux at $35^{\circ} \mathrm{S}$. The southward flux started on 24 August, the plume was near the surface between $60^{\circ}$ and $50^{\circ} \mathrm{W}$, with values from -60 to -120 $\mu \mathrm{gm}^{-2} \mathrm{~s}^{-1}$.
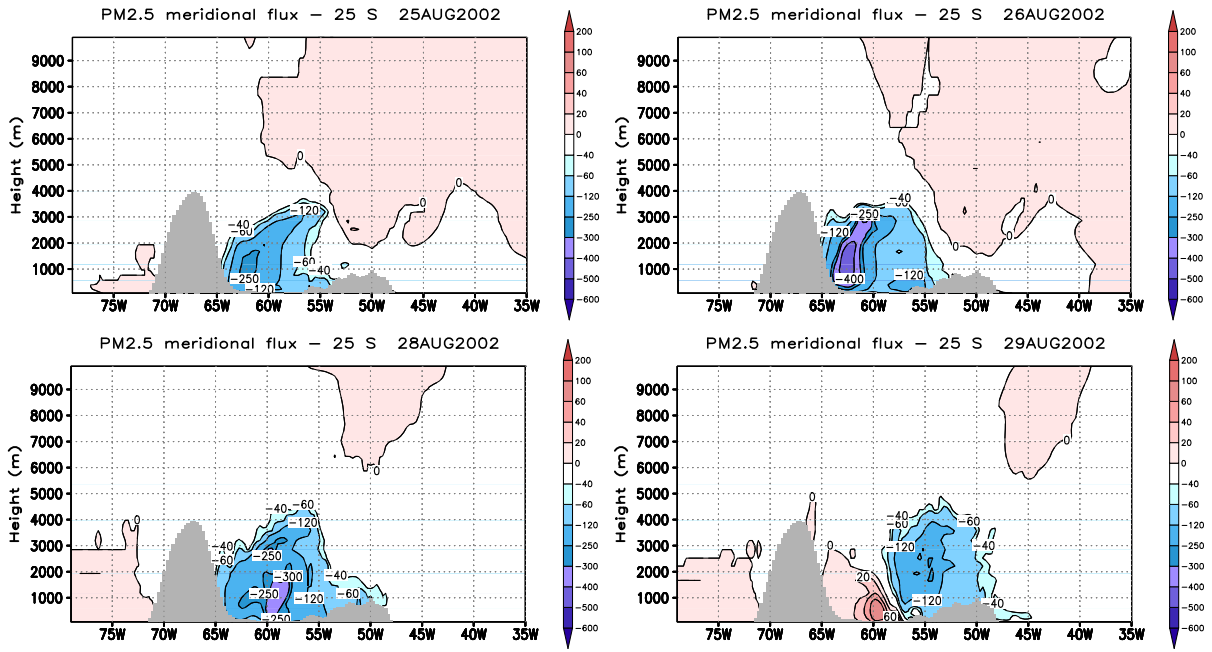

Fig. 10b. Vertical cross-sections at $25^{\circ} \mathrm{S}$ of PM2.5 meridional transport $\left(\mu \mathrm{gm}^{-2} \mathrm{~s}^{-1}\right)$ against the height above the surface. Terrain height profile is included.
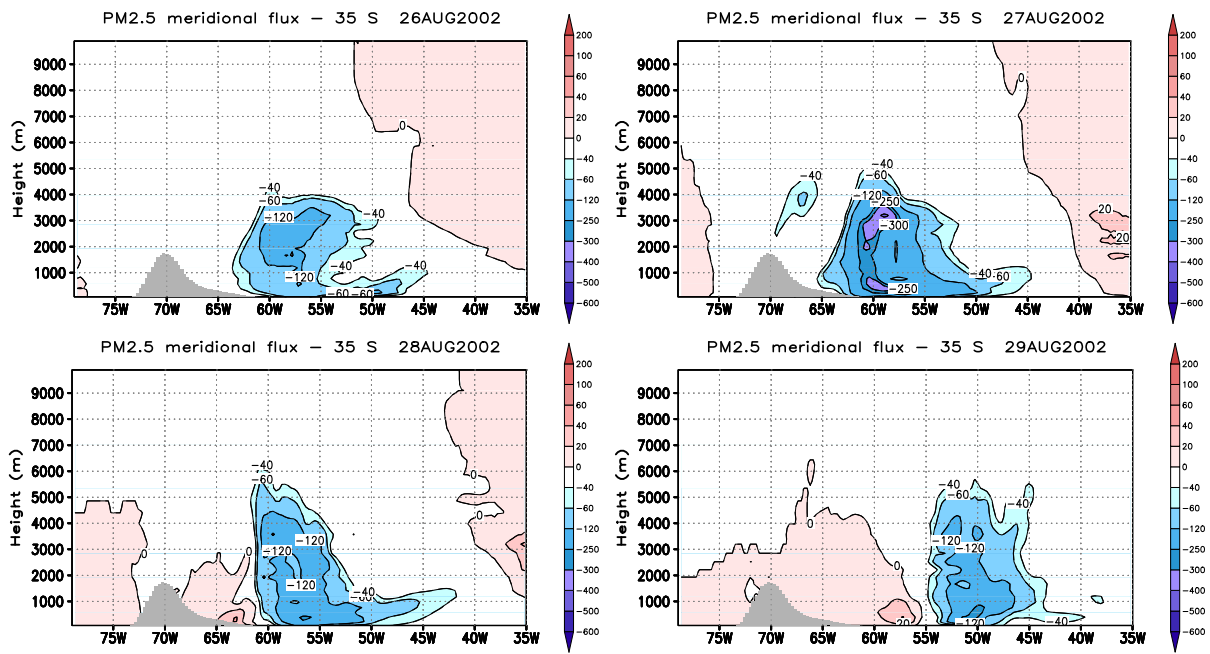

Fig. 10c. Vertical cross-sections at $35^{\circ} \mathrm{S}$ of PM2.5 meridional transport $\left(\mu \mathrm{gm}^{-2} \mathrm{~s}^{-1}\right)$ against the height above the surface. Terrain height profile is included.

During the next day, two maxima appeared, one located near the surface and the other one centred at $2000 \mathrm{~m}$ and values ranging from -60 to $-120 \mu \mathrm{gm}^{-2} \mathrm{~s}^{-1}$. During 26 August, the upper 
level maximum, centred at $2500 \mathrm{~m}$ and east of $60^{\circ} \mathrm{W}$ strengthened, the values ranged from 60 to $-360 \mu \mathrm{gm}^{-2} \mathrm{~s}^{-1}$. On 27 August the southward transport was widespread and ranged from -60 to $-420 \mathrm{\mu gm}^{-2} \mathrm{~s}^{-1}$. On the following day, the smoke transport extended up to $5000 \mathrm{~m}$, remaining towards the south and east of $60^{\circ} \mathrm{W}$ and the maximum values ranged from -60 to $-360 \mathrm{\mu gm}^{-2} \mathrm{~s}^{-1}$. Close to the mountains a northward transport occurred near the surface, with

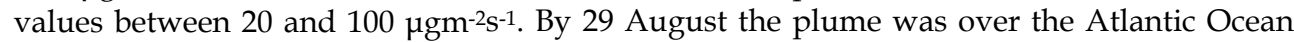
and the northward transport was west of $55^{\circ} \mathrm{W}$, ranging from 40 to $60 \mathrm{\mu gm}^{-2} \mathrm{~s}^{-1}$. During the next two days the flux gradually disappeared at this latitude due to the fast movement of the cold front.
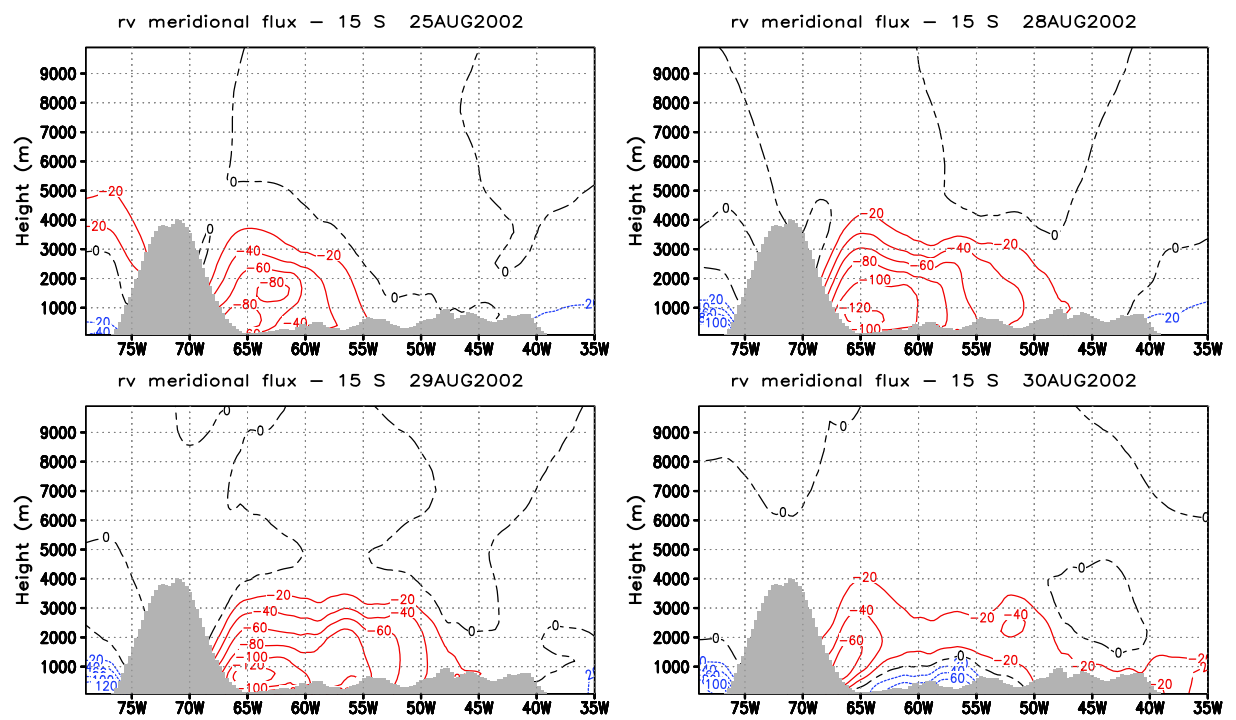

Fig. 11a. Vertical cross-sections at $15^{\circ} \mathrm{S}$ of water vapour mixing ratio meridional transport (g $\mathrm{m} \mathrm{kg}^{-1} \mathrm{~s}^{-1}$ ) against the height above the surface. Terrain height profile is included.

Figure 11 shows the vertical cross sections at similar latitudes, but illustrates in this case, the water vapour meridional transport. At $15^{\circ} \mathrm{S}$ (Figure 11a) on 23 August there was a prevalence of the southward transport of water vapour, spanning from $72.5^{\circ} \mathrm{W}$ to $47^{\circ} \mathrm{W}$, from the surface up to $3000 \mathrm{~m}$, and the maximum flux centred at $1500 \mathrm{~m}$ with a mean daily value of $-60 \mathrm{gmkg}^{-1} \mathrm{~s}^{-1}$. The northward transport took place over the oceans near the surface. The next day the pattern was similar and the value of the meridional flux increased. On the following three days the longitudinal extent of the zone with southward flux was narrower and the values -80 and $-60 \mathrm{gmkg}^{-1} \mathrm{~s}^{-1}$ respectively. West of the Andes, at upper levels the water vapour southward flux also occurred. The northward transport over the oceans was still present. On 28 and 29 August the longitudinal extent increased as well as the value of the maximum flux, the difference is the location near the surface. The northward water vapour transport increased over the Pacific Ocean. During 30 August, the incursion of the cold front caused a northward flux near the surface between $65^{\circ}$ and $50^{\circ} \mathrm{W}$. The flux from the north was restricted next to the Andes centred at $1000 \mathrm{~m}$. The following day the pattern was nearly similar, with a decrease in the southward transport. 
At $25^{\circ} \mathrm{S}$ (Figure 11b) from 23 to 28 August, there was a southward flux at all longitudes east of the Andes from the surface up to middle levels in the troposphere.
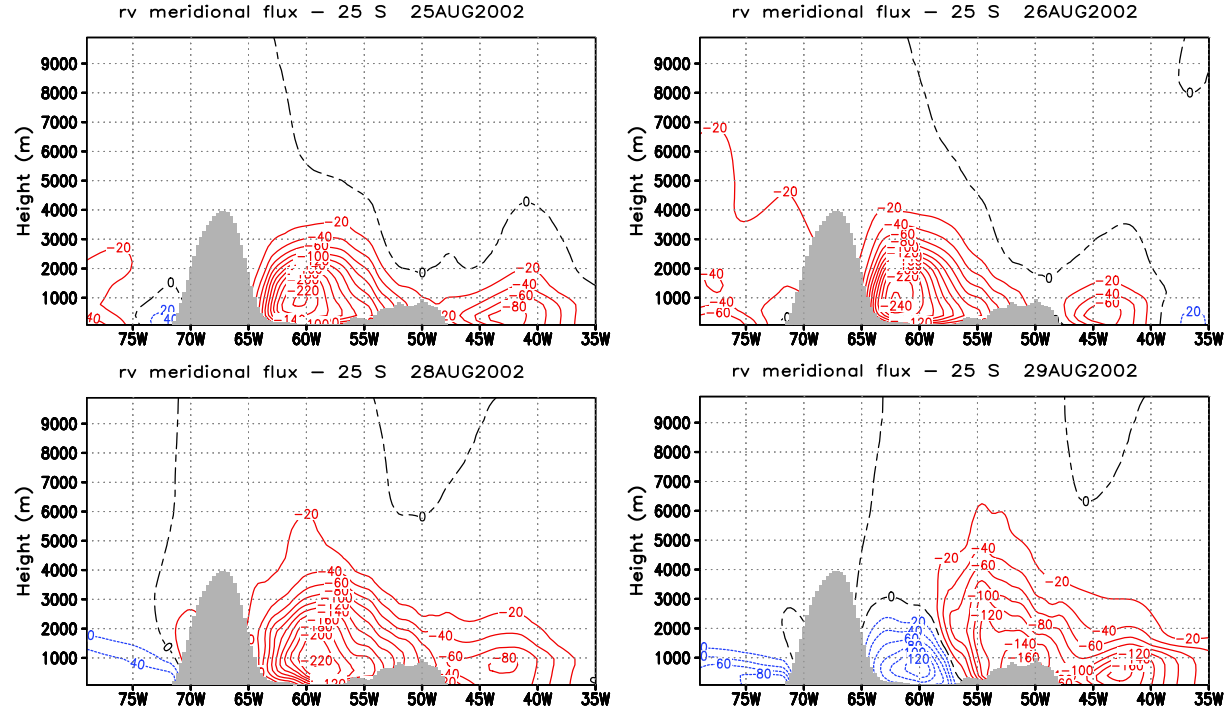

Fig. 11b. Vertical cross-sections at $25^{\circ} \mathrm{S}$ of water vapour mixing ratio meridional transport (g $\mathrm{m} \mathrm{kg}^{-1} \mathrm{~s}^{-1}$ ) against the height above the surface. Terrain height profile is included.
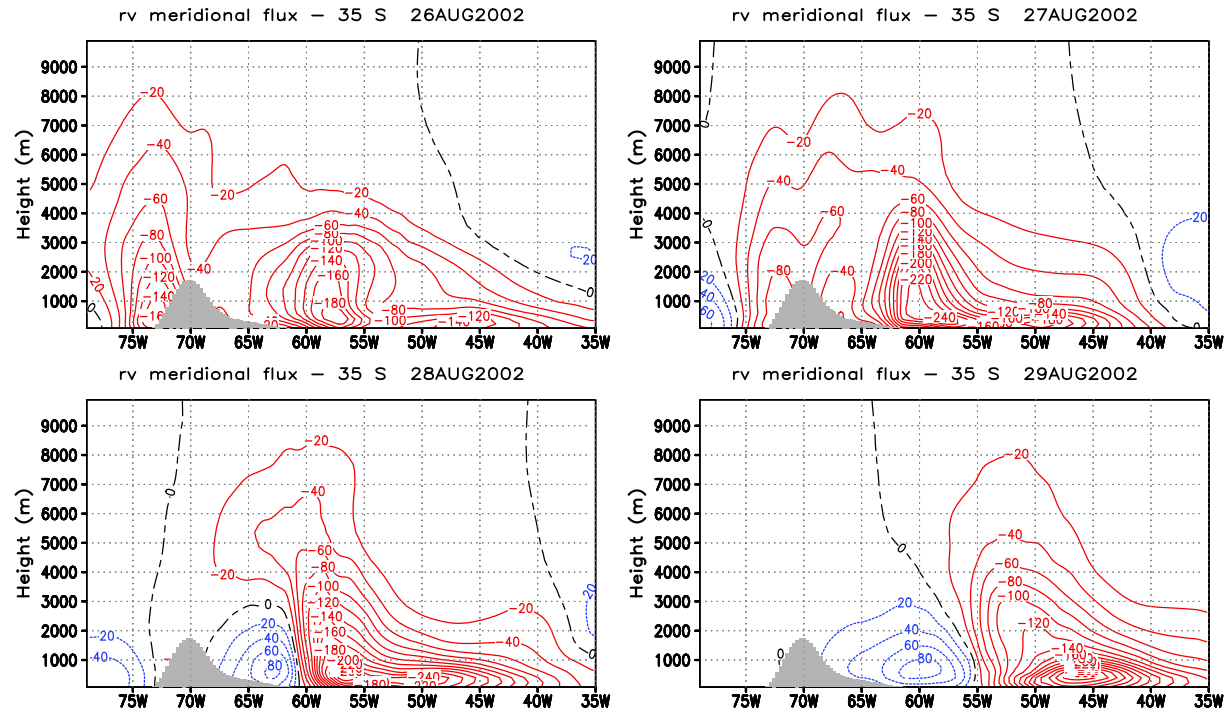

Fig. 11c. Vertical cross-sections at $35^{\circ} \mathrm{S}$ of water vapour mixing ratio meridional transport (g $\mathrm{m} \mathrm{kg}^{-1} \mathrm{~s}^{-1}$ ) against the height above the surface. Terrain height profile is included. 
The values ranged from -140 to $-260 \mathrm{gmkg}^{-1} \mathrm{~s}^{-1}$. West of the mountain range, the southward flux also occurred on 26 and 27 August reaching a daily maximum of $-80 \mathrm{gmkg}^{-1} \mathrm{~s}^{-1}$. From 29 to 31 August the progression of the cold front caused a northward flow that varied between 20 and $120 \mathrm{gmkg}^{-1} \mathrm{~s}^{-1}$ with a longitudinal range that moved to the east.

Figure 11c depicts the water vapour meridional transport at $35^{\circ} \mathrm{S}$. The southward water vapour transport was present from 23 to 27 August from the surface up to $8000 \mathrm{~m}$ and $75^{\circ} \mathrm{W}$ and $35^{\circ} \mathrm{W}$, the maximum values varied from -100 to $-260 \mathrm{gmkg}^{-1} \mathrm{~s}^{-1}$. The opposite transport directions associated with the surface cold front is sharply marked in the cross-sections on 28 and 29 August, and the maximum values are located near the surface. The next days showed the contrast in the air masses water vapour as well.

\subsection{Case study: October 2002}

This event extended from 17 to 21 October and was characterised by a variable low level flow pattern, which had a short SALLJ episode and a changing meteorological scenario, with transient perturbations of short duration.

\subsubsection{Meteorological environment and SALLJ features}

On 17 October, the $1000 \mathrm{hPa}$ height shows the dominance of a post-frontal high pressure system over central Argentina (Figure 12). The surface front is located over central South America. On the south-western region of Argentina, the 500/1000 hPa depths show a baroclinic zone associated with a new frontal system.

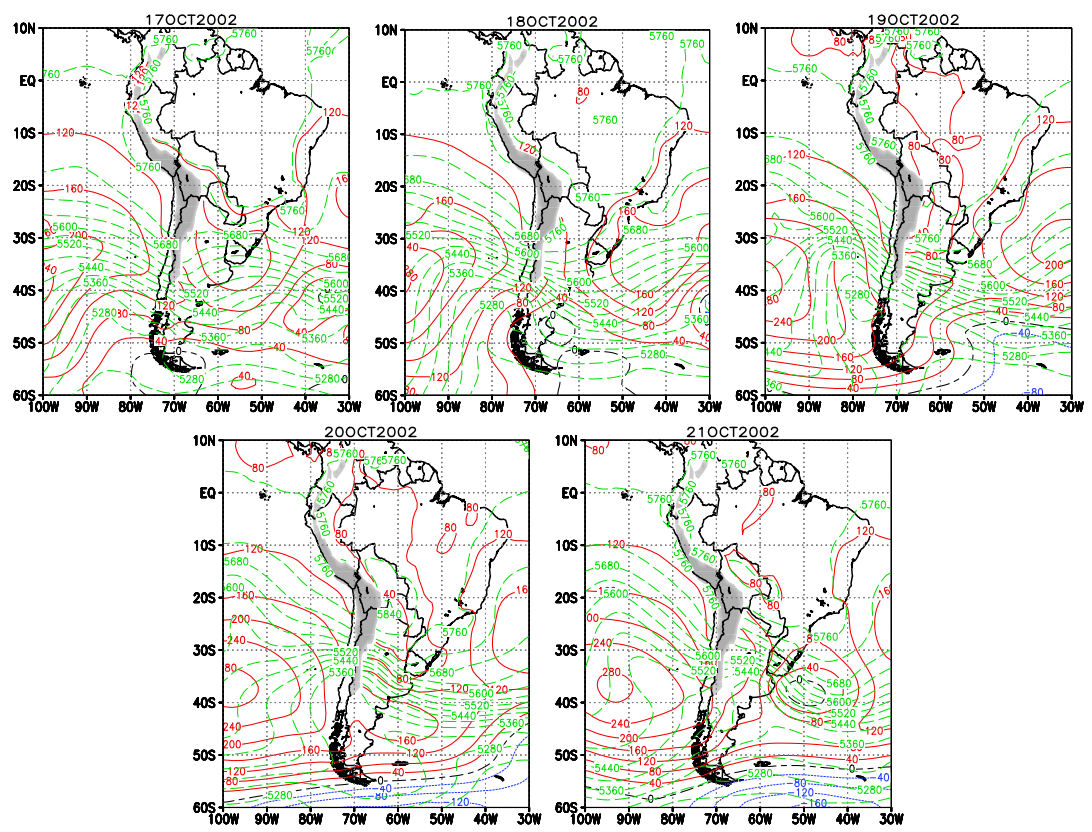

Fig. 12. Daily fields of $1000 \mathrm{hPa}$ geopotential height (red solid (positive), blue dot (negative) contours) and 500/1000 hPa thickness (green long dash contours) (both every $40 \mathrm{mgp}$ ), from 17 to 21 October. Terrain elevations higher than $1500 \mathrm{~m}$ are shaded. 
During the following day, the anticyclone moved to the Atlantic Ocean, centred about $40^{\circ} \mathrm{W}$ and $35^{\circ} \mathrm{S}$. Behind the baroclinic zone, a low pressure system located near $65^{\circ} \mathrm{W}$ and $47^{\circ} \mathrm{S}$, developed. A thickness through oriented from the NW to the SE, is observed over the Pacific Ocean associated to an upper air through. The low level flow over north-eastern Argentina was from the north. On 19 October, the surface low pressure region had a fast displacement towards the SE. On the other hand, an anticyclonic system moved eastward covering the southern region of Argentina. North of $30^{\circ} \mathrm{S}$, central South America showed relatively lower pressures. By 20 October, the thickness through axis was over Los Andes Mountains and then moved eastward. The low pressure system on central-northern Argentina displaced to the east and accordingly, the flow near the surface turned and blew from the east over Buenos Aires. On 21 October, a low pressure system developed and evolved in agreement with the displacement of the pattern at upper levels. It is located around $40^{\circ} \mathrm{S}$ and $50^{\circ} \mathrm{W}$. Argentina was under the influence of an extended anticyclone. The near surface flow was from the south.
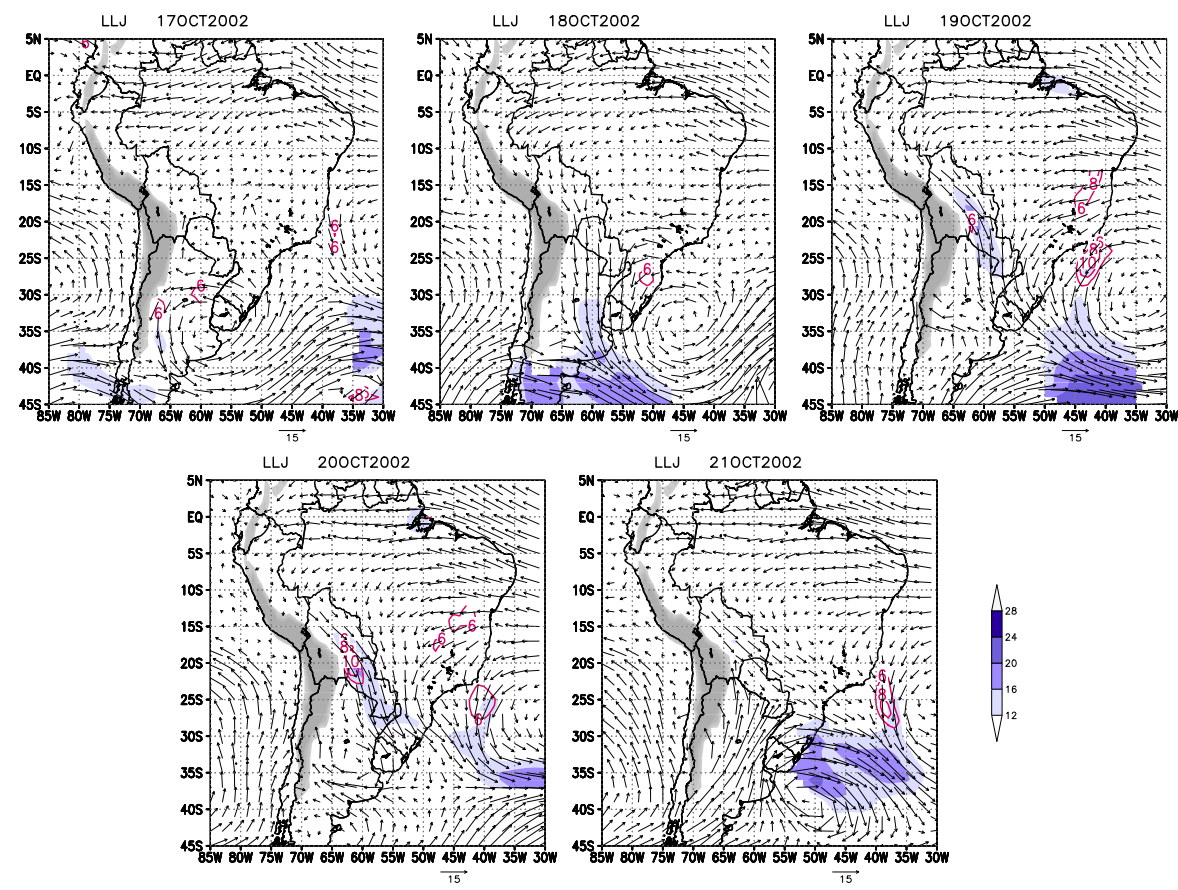

Fig. 13. Daily SALLJ fields from 17 to 21 October. Wind (vector); wind speed (shaded) at 850 $\mathrm{hPa}$ and wind shear between $850 \mathrm{hPa}$ and $700 \mathrm{hPa}$ (contours). Shaded: wind intensity stronger than $12 \mathrm{~m} \mathrm{~s}^{-1}$. Contours: wind shear greater than $6 \mathrm{~m} \mathrm{~s}^{-1}$. Terrain elevations higher than 1500 $\mathrm{m}$ are shown.

Figure 13 illustrates the $850 \mathrm{hPa}$ flow and SALLJ features. On 17 October the low level flow associated to the post-frontal anticyclone centred over Buenos Aires is clearly shown. A very weak SALLJ is evident in the 850-700 layer, between Los Andes and the west of an anticyclone. The smaller wind intensities are observed over the biomass burning source 
regions. By 18 October, the low level flow strengthened and organized in a northerly current due to the approach from the southwest of the new cold front and the presence of the anticyclone now centred at $45^{\circ} \mathrm{W}$ and $35^{\circ} \mathrm{S}$ over the Atlantic Ocean. The $850 \mathrm{hPa}$ winds did not satisfy the Bonner criteria. The north-western edge of the cold front is located near $35^{\circ} \mathrm{S}$ and $65^{\circ} \mathrm{W}$. On 19 October the SALLJ spanned from central Bolivia to Paraguay and northern Argentina. The wind was from the north. Buenos Aires was behind the cold front. Another region with low level jet occurrence is over the Atlantic Ocean centred at $15^{\circ} \mathrm{S}$. South of $30^{\circ}$ $\mathrm{S}$, the flow turned counter clockwise and acquired a north-western orientation ahead of the cold front. On 20 October, a SALLJ occurred, with its southern edge near $30^{\circ} \mathrm{S}$. The front remained stationary over central Argentina. A low pressure system developed in the central region of Argentina whereas the exit region of the SALLJ was on southern Brazil. During the next day, there is a clear evidence of a strengthening and rapid displacement of the cold front that is oriented NW to SE. The low-level flow was from the south up to $20^{\circ} \mathrm{S}$.

\subsubsection{Concentration behaviour}

On 17 October, the vertically integrated AOT clearly depicts the constraint on the southward displacement imposed by the cold front (Figure 14). The higher AOT are observed near the sources in close agreement with the regions in which the smaller wind speeds occurred. As the post-frontal anticyclone moves eastward, the southward transport of the smoke plume is favoured on its western region. In this particular case, the AOT values are low, indicative of relatively clean air, but the contrary might happen with greater emissions. Northern Argentina had AOT greater than 1. During the next day, with the displacement of the anticyclone towards the Atlantic Ocean and the further re-establishment of the northwestern flow, AOT over 0.3 reached Buenos Aires. On 19 October, the smoke plume is narrower and the AOT greater than 1.25 reached southern Brazil. On the other hand, over Buenos Aires and Córdoba the AOT ranged from 0.2 to 0.5. During the next day, the greater AOT are observed near the source region. An interesting feature is that a relative minimum occurs in the same location than the SALLJ core over central Bolivia and northern Paraguay. On central Argentina, the development of the cyclonic circulation further helps the transport to the south on its eastern flank. AOT values ranging from 0.3 to 0.5 are predicted over Buenos Aires. On 21 October the strong south-westerly winds that blew over central Argentina caused the displacement of the smoke plume towards lower latitudes. The southern edge of the plume clearly shows the shape of the frontal region.

\subsubsection{Meridional PM2.5 and water vapour transport}

Figure 15 shows the PM2.5 meridional transport. At $20^{\circ} \mathrm{S}$ (Figure 15a), during 17 October, there was a northward transport in the layer ranging from near the surface to $1500 \mathrm{~m}$, between $65^{\circ} \mathrm{W}$ and $55^{\circ} \mathrm{W}$. The values ranged from 20 to $220 \mu \mathrm{gm}^{-2} \mathrm{~s}^{-1}$. This agrees with the higher concentrations in the regional plume. Immediately above this maximum there was a southward flow reaching the upper troposphere. The maximum meridional transport towards the south was centred at about $2500 \mathrm{~m}$ and $60^{\circ} \mathrm{W}$, with values between -60 and -180 $\mu \mathrm{gm}^{-2} \mathrm{~s}^{-1}$. This agrees with the flow pattern that was perturbed by the presence of the NW edge of the cold front. As the front moved north-eastward the northern meridional flow reestablished co-located with the SALLJ. On the following day, the southward transport strengthened while the northward flow east of $60^{\circ} \mathrm{W}$ weakened, as well as its vertical 


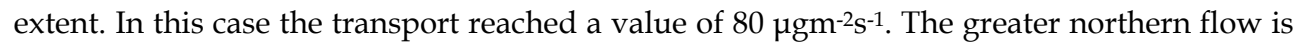
observed in the longitudes between $65^{\circ} \mathrm{W}$ and $55^{\circ} \mathrm{W}$ centred at $2000 \mathrm{~m}$ and reached a maximum of $-240 \mathrm{\mu gm}^{-2} \mathrm{~s}^{-1}$. On 19 and 20 October the southward transport is dominant and the maximum values (-240 and $-300 \mu \mathrm{gm}^{-2} \mathrm{~s}^{-1}$, respectively) appear closer to the surface with an eastward displacement. The pattern remained almost similar on 21 October, with a slight decrease in the southward transport.
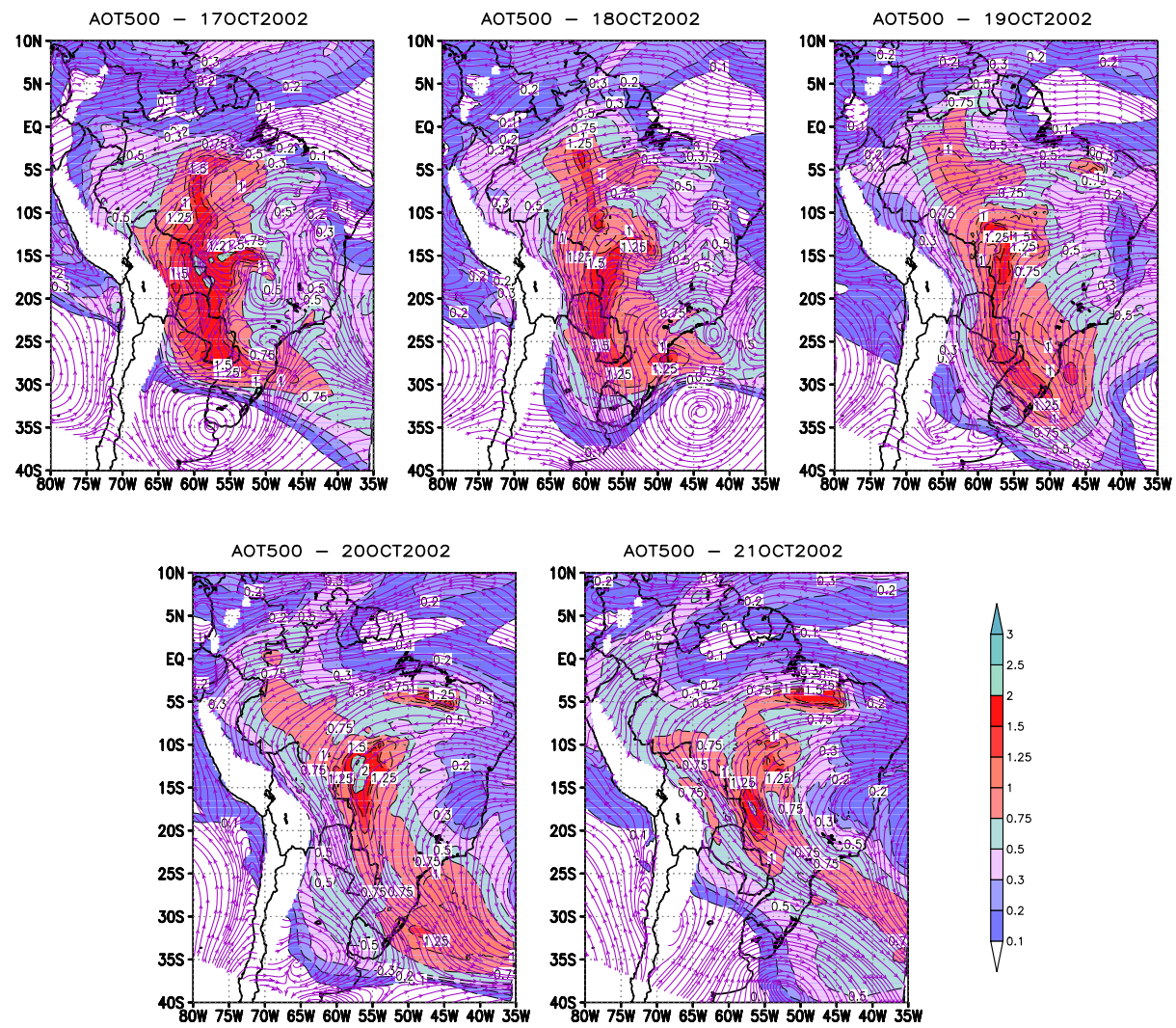

Fig. 14. Daily means of AOT500nm from 17 to 21 August (shaded) and wind field (streamlines) at $1400 \mathrm{~m}$ above the surface.

At the southernmost latitude considered in the vertical cross sections $-30^{\circ} \mathrm{S}$ - (Figure $15 \mathrm{~b}$ ) during 17 October, the transport was from the south in the longitudes ranging from $60^{\circ} \mathrm{W}$ to $45^{\circ} \mathrm{W}$ from the surface up to $2000 \mathrm{~m}$, reaching a maximum value of $-240 \mu \mathrm{gm}^{-2} \mathrm{~s}^{-1}$. On the next day, the flux was from the north in a layer from the surface up to middle troposphere, from $65^{\circ} \mathrm{W}$ and $50^{\circ} \mathrm{W}$. The greatest value was $-180 \mu \mathrm{gm}^{-2} \mathrm{~s}^{-1}$ centred at $57^{\circ} \mathrm{W}$ and $1500 \mathrm{~m}$. The northward transport was smaller and over the Atlantic Ocean. During 19 October, the dominance of the southward transport was evident in the layer from the surface up to $3000 \mathrm{~m}$ where had its greatest strength. The following day showed almost similar shape, with a slight decrease in the intensities. 

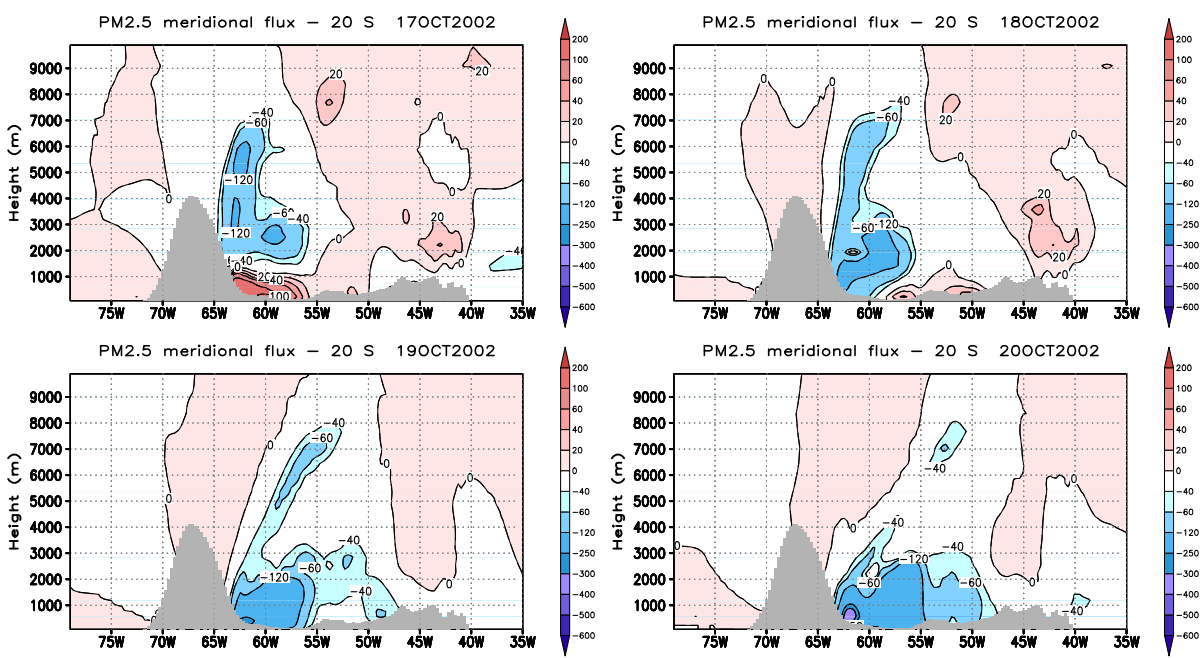

Fig. 15a. Vertical cross-sections at $20^{\circ} \mathrm{S}$ of PM2.5 meridional transport $\left(\mu \mathrm{gm}^{-2} \mathrm{~s}^{-1}\right)$ against the height above the surface. Terrain height profile is included.
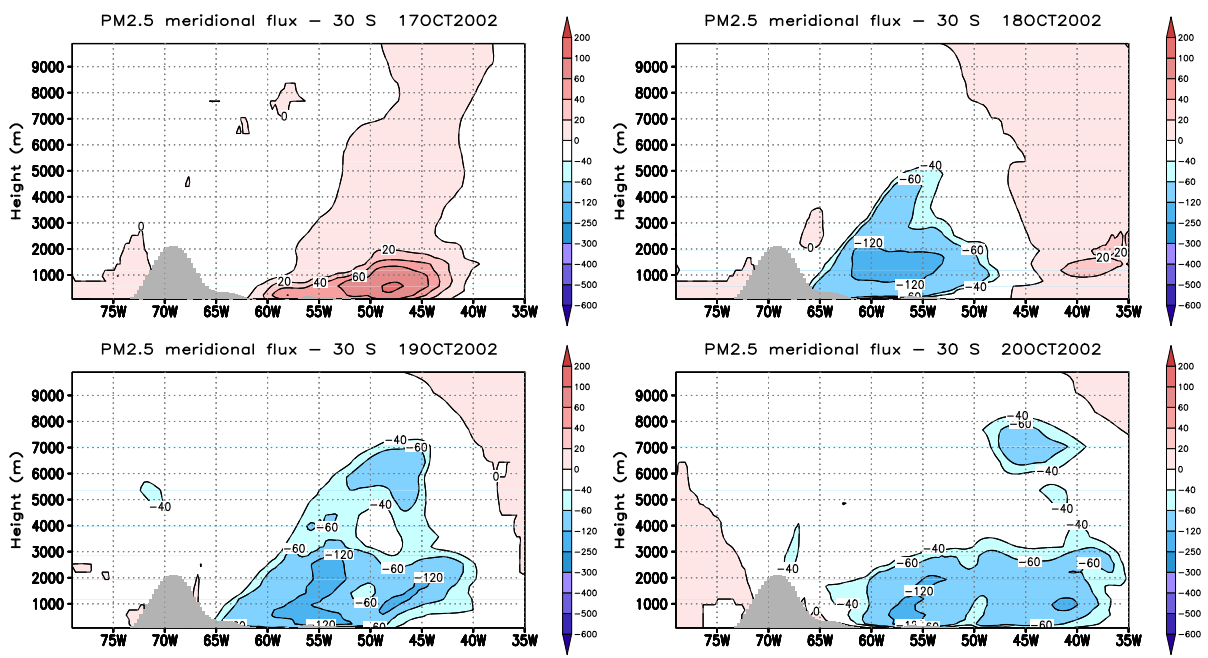

Fig. 15b. Vertical cross-sections at $30^{\circ} \mathrm{S}$ of PM2.5 meridional transport $\left(\mu \mathrm{gm}^{-2} \mathrm{~s}^{-1}\right)$ against the height above the surface. Terrain height profile is included.

On 21 October, the vertical cross section shows northward transport associated with the progression of the cold front, from $65^{\circ} \mathrm{W}$ to $55^{\circ} \mathrm{W}$ in the layer near the surface up to $1000 \mathrm{~m}$, and the opposite flux over the Atlantic Ocean, east of $45^{\circ} \mathrm{W}$. The values reached 120 and -

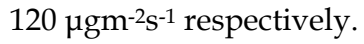



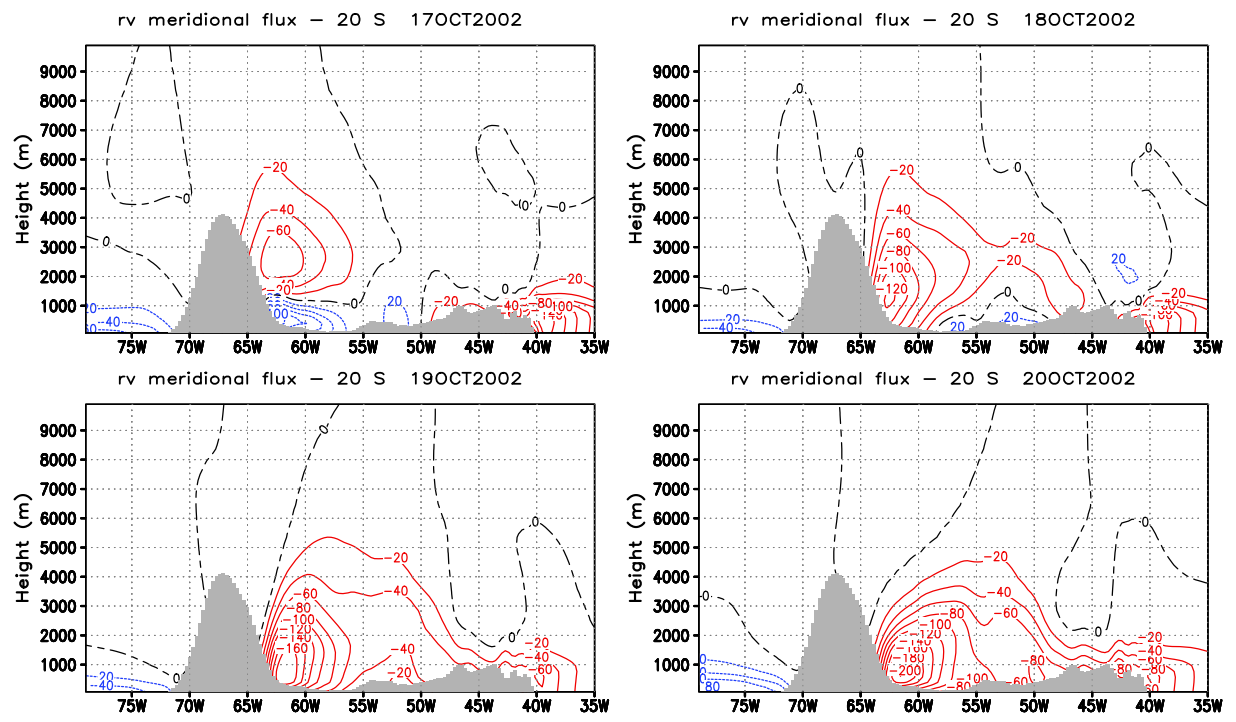

Fig. 16a. Vertical cross-sections at $20^{\circ} \mathrm{S}$ of water vapor mixing ratio meridional transport (g $\mathrm{m} \mathrm{kg}^{-1} \mathrm{~s}^{-1}$ ) against the height above the surface. Terrain height profile is included.

The water vapour meridional flow at $20^{\circ} \mathrm{S}$ (Figure 16a) on 17 October, showed opposite flows immediately east of the Andes, with northward water vapour flux near the surface up to $1000 \mathrm{~m}$ and the contrary above this height. Contrarily to what happened with the PM2.5 transport, the southward transport east of $50^{\circ} \mathrm{W}$ was greater than that observed near the mountains, and this is related to the location of the water vapour and particulate sources. The southward transport reached values equal $-80 \mathrm{gmkg}^{-1} \mathrm{~s}^{-1}$ at $62.5^{\circ} \mathrm{W}$ and $-140 \mathrm{gmkg}^{-1} \mathrm{~s}^{-1}$ at $-42.5^{\circ} \mathrm{W}$ during this day. On 18 October, the transport to the south was dominant with a strengthening of the maximum close to the Andes, with a mean daily value equal to -120 gmkg-1 $^{-1} \mathrm{~S}^{-1}$. The next two days, in accordance with the occurrence of the SALLJ, the transport to the south was dominant at this latitude, with the highest value coincident with the jet core, reaching $-220 \mathrm{gmkg}^{-1} \mathrm{~s}^{-1}$. On 21 October the region with southward flux moved slightly to the east, and the highest value was $-160 \mathrm{gmkg}^{-1} \mathrm{~s}^{-1}$.

At $30^{\circ} \mathrm{S}$ (Figure 16b), on 17 October, there was northward transport near the surface from $60^{\circ} \mathrm{W}$ to $42^{\circ} \mathrm{W}$, with a maximum value of $140 \mathrm{gmkg}^{-1} \mathrm{~s}^{-1}$. The flux to the south took place in a narrow region close to the Andes and reached $-60 \mathrm{gmkg}^{-1} \mathrm{~s}^{-1}$. Another zone with southward transport was over the Atlantic. During the next day, the region with southward transport extended to $47^{\circ} \mathrm{W}$, with the highest value below $1000 \mathrm{~m}$, centred at $55^{\circ} \mathrm{W}$. An interesting feature is that the transport of water vapour and PM2.5 maximize in different altitudes and longitudes. This difference is also evident on 19 October, when the maximum water vapour transport reached $-180 \mathrm{gmkg}^{-1} \mathrm{~s}^{-1}$. The following day, the southward flux had two maxima below $1000 \mathrm{~m}$, one centred at $57^{\circ} \mathrm{W}$ and the other one at $42^{\circ} \mathrm{W}$. The values reached -180 gmkg-1 $\mathrm{s}^{-1}$. On 21 October, $55^{\circ} \mathrm{W}$ marked the divide between the flux towards the north and the south in coincidence with the PM2.5 transport, but, once more, the layers of transport were different. 

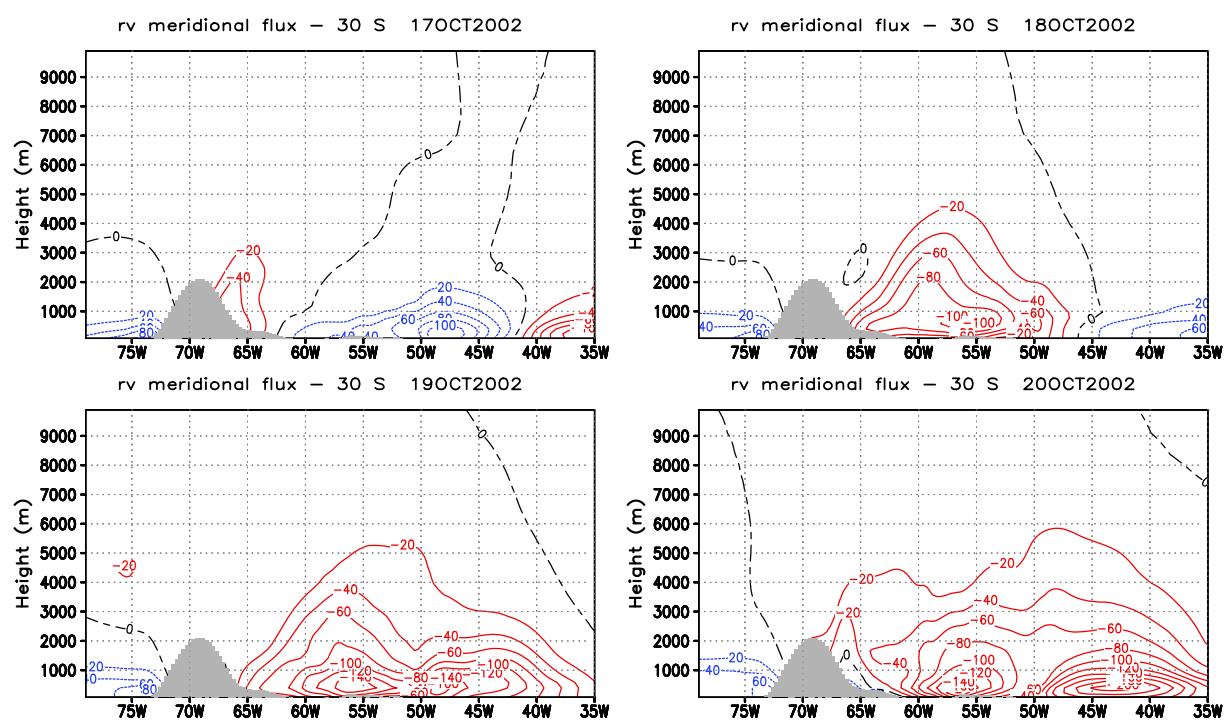

Fig. 16b. Vertical cross-sections at $30^{\circ} \mathrm{S}$ of water vapor mixing ratio meridional transport (g $\mathrm{m} \mathrm{kg}^{-1} \mathrm{~s}^{-1}$ ) against the height above the surface. Terrain height profile is included.

\section{Discussion}

The fire spots experience an important increase during the dry season in Tropical South America and the regional smoke plume is driven by the low level flow. The South American Low Level Jet is a frequent pattern that contributes and patronizes the dispersion and its importance was documented. The smoke plume can travel a long distance from the source region and cause several impacts on remote locations. Among these effects are the increase in the aerosol load and characteristics.

The pattern that emerges in the prolonged episode in August is that during the warm stage of the cold front incursion, the southward penetration of the smoke is favoured. The level of the transport is in close relationship with the maximum meridional wind that develops in the SALLJ event. Owing to the cold front displacement, there is a northward transport of the regional plume. Behind the cold front the air is clean. The horizontal transport mechanism is related to the tangential component of the wind, parallel to the frontal region. Therefore, ahead of the front, there is a preferred exit region from South America towards the Atlantic Ocean. Another interesting feature is that the material is forced to ascend at the frontal slope, and the level of maximum transport occurs at higher levels in the cold stage, so they are generally uncoupled from the surface and above the atmospheric boundary layer.

The regional transport of smoke is clearly shown. The smoke plume originated in the vegetation fires over tropical South America and was transported first westward, then deflected by the Andes barrier and finally southward, reaching mid-latitude regions farther south of $40^{\circ} \mathrm{S}$. The cold front approach moved afterwards the polluted air mass towards southeastern Brazil and the Atlantic Ocean.

In the October episode, the short duration transient systems contributed to the dispersion and re-circulation of the smoke plume. The southward incursion of the smoke plume was 
prevented by the fast displacement of a cold front, and in this case the exit to the Atlantic was observed over southern Brazil. The post-frontal anticyclonic circulations favoured the incursion of the plume over Argentina near the Andes.

It is worthy to point out that, in both cases, within the scenario of regional transport and interaction with the greater scale weather patterns, there is a mesoscale effect of the low level jet clearly evident in the region of the SALLJ core: a relative minimum in the AOT values. As regards the vertical distribution and preferred levels of dispersion, the importance of the SALLJ as a transport mechanism was demonstrated. The main difference between biomass burning products and water vapour is related to the longitudinal span of the transport, which arises from the spatial distribution of the sources. One distinctive feature is that the water vapour transport takes place at lower levels as compared with the particulate material transport.

\section{Conclusion}

A study of the relationship of the South American Low Level Jet east of the Andes and the regional transport of biomass burning products was carried out. The detailed threedimensional structure and evolution of the meteorological and aerosols fields contributed to depict the preferred regions and levels in which the transport of the biomass burning products took place. The South American Low Level Jet is an agent to transport and mix biogeochemical substances and therefore, a possible impact on regional climate could occur in association with burning and destruction of the tropical rain forest. Biomass burning smoke effects must be included in climate models issuing to make any assessment of the regional climate change in the South American continent.

\section{Acknowledgment}

This research was partially funded by UBACyT X224 and ANPCyT PICT 08-1739 projects. NCEP is acknowledged for the meteorological analyses and Brent Holben for the AERONET data.

\section{References}

Bonner, W. D. (1968). Climatology of the low level jet. Monthly Weather Review, Vol.119, pp. 1575-1589, ISSN 0027-0644.

Freitas, S. R.; Longo, K. M.; Silva Dias, M. A. F.; Chatfield, R.; Silva Dias, P.; Artaxo, P.; Andreae, M. O.; Grell, G.; Rodrigues, L. F.; Fazenda, A. \& Panetta, J. (2009). The Coupled Aerosol and Tracer Transport model to the Brazilian developments on the Regional Atmospheric Modeling System (CATT-BRAMS) Part 1: Model description and evaluation. Atmospheric Chemistry and Physics, Vol. 9, pp. 2843-2861, ISSN 16807316.

James, I. N. \& Anderson, D. L. T. (1984). The seasonal mean flow and distribution of largescale weather systems in the southern hemisphere: the effects of moisture transport. Quarterly eburnal Royal Meteorological Society, Vol. 110, pp. 943-966, ISSN 1477-870X.

Longo, K. M.; Freitas, S. R.; Andreae, M. O.; Setzer, A.; Prins, E. M. \& Artaxo, P. (2010). The Coupled Aerosol and Tracer Transport model to the Brazilian developments on the 
Regional Atmospheric Modeling System (CATT-BRAMS) Part 2: Model sensitivity to the biomass burning inventories. Atmospheric Chemistry and Physics, Vol. 10, pp. 5785-5795, ISSN 1680-7316.

Nicolini, M.; Saulo C.; Torres, J. C. \& Salio, P. (2002). Enhanced precipitation over southeastern South America related to strong low-level jet events during austral warm season. METEOROLOGICA, Special Issue for the South American Monsoon System, Vol. 27, pp. 59-69, ISSN 0325-187X.

Nogues-Paegle, J. \& Mo, K. C. (1997). Alternating wet and dry conditions over South America during summer. Monthly Weather Review, Vol. 125, pp. 279-291, ISSN 00270644.

Nogues-Paegle, J., K. C. Mo \& Paegle J. (1998). Predictability of the NCEP-NCAR Reanalysis Model during Austral Summer. Monthly Weather Review, Vol. 126, pp. 3135-3152, ISSN 0027-0644.

Paegle, J. (1998). A comparative review of South American low level jets. METEOROLOGICA, Vol. 23, pp. 73-81, ISSN 0325-187X.

Saulo, C., Nicolini, M. \& Chou, S. C. (2000). Model characterization of the South American low-level flow during 1997-1998 spring-summer season. Climate Dynamics, Vol. 16, pp. 867-881, ISSN 0930-7575.

Vera C. S. \& collaborators (2006). The South American Low Level Jet Experiment, Bulletin of the American Meteorological Society, Vol. 87, pp. 63-77, ISSN 0003-0007. 


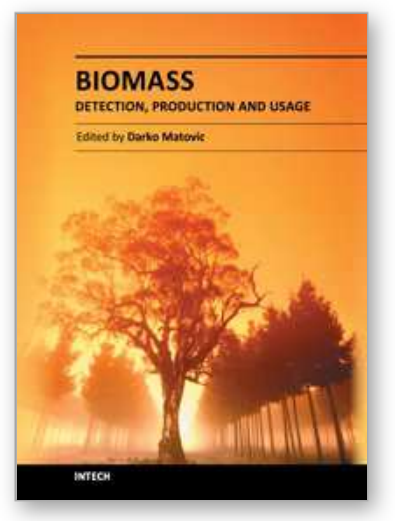

\author{
Biomass - Detection, Production and Usage \\ Edited by Dr. Darko Matovic
}

ISBN 978-953-307-492-4

Hard cover, 496 pages

Publisher InTech

Published online 09, September, 2011

Published in print edition September, 2011

Biomass has been an intimate companion of humans from the dawn of civilization to the present. Its use as food, energy source, body cover and as construction material established the key areas of biomass usage that extend to this day. Given the complexities of biomass as a source of multiple end products, this volume sheds new light to the whole spectrum of biomass related topics by highlighting the new and reviewing the existing methods of its detection, production and usage. We hope that the readers will find valuable information and exciting new material in its chapters.

\title{
How to reference
}

In order to correctly reference this scholarly work, feel free to copy and paste the following:

Ana Graciela Ulke, Karla María Longo and Saulo Ribeiro de Freitas (2011). Biomass Burning in South America: Transport Patterns and Impacts, Biomass - Detection, Production and Usage, Dr. Darko Matovic (Ed.), ISBN: 978-953-307-492-4, InTech, Available from: http://www.intechopen.com/books/biomass-detectionproduction-and-usage/biomass-burning-in-south-america-transport-patterns-and-impacts

\section{INTECH}

open science / open minds

\section{InTech Europe}

University Campus STeP Ri

Slavka Krautzeka 83/A

51000 Rijeka, Croatia

Phone: +385 (51) 770447

Fax: +385 (51) 686166

www.intechopen.com

\section{InTech China}

Unit 405, Office Block, Hotel Equatorial Shanghai

No.65, Yan An Road (West), Shanghai, 200040, China

中国上海市延安西路65号上海国际贵都大饭店办公楼 405 单元

Phone: +86-21-62489820

Fax: +86-21-62489821 
(C) 2011 The Author(s). Licensee IntechOpen. This chapter is distributed under the terms of the Creative Commons Attribution-NonCommercialShareAlike-3.0 License, which permits use, distribution and reproduction for non-commercial purposes, provided the original is properly cited and derivative works building on this content are distributed under the same license. 